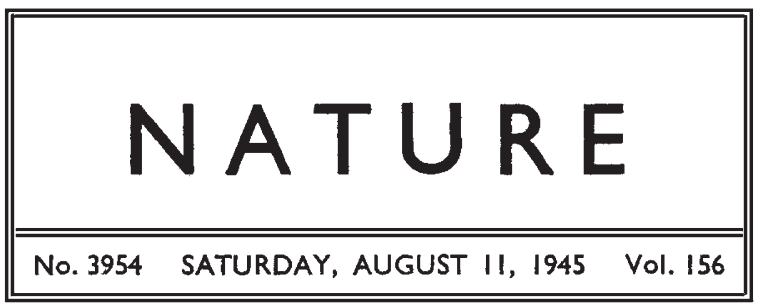

CONTENTS

Atomic Energy: an International Responsibility Man-Power and Training in the Scientific Instrument Industry

Volcanic Forms and Structures. By Prof. Árthur Holmes, F.R.S.

Child Guidance Grows Up. By Dr. Alan Maberly

Climatology for Meteorologists. By Prof. D. Brunt, F.R.S.

The Race Problem in South America. By Prof. A. R. Radcliffe-Brown

The Secretion of Milk. By Prof. H. D. Kay, O.B.E., F.R.S.

Cervico-Facial Pigmentation (Melanosis of Riehl-Poikiloderma). By Dr. Georges Garnier

News and Views

Letters to the Editors:

Insecticidal Action of D.D.T.-J. R. Busvine

Cation and Anion Permeability Constants for the Muscle Fibre Membrane.-Prof. E. J. Conway and P. T. Moore

Anti-bacterial Action of 'Polyporin' against Typhoid, Cholera, Dysentery and B. coli.-Prof. S. R. Bose

Microbiological Assay of Riboflavin.-Staniey $\dot{A}^{\circ}$. Price

Records of Culex (Barraudius) modestus Ficalbi (Diptera, Culicidx) obtained in the South of England.-John F. Marshall, C.B.E. . . .

Granules of the Human Polymorphonuclear Leucocyte.-Major J. F. A. McManus

Origin of Haploid-Diploid Twin Embryos in Angiosperms.-Dr. P. Maheshwari.

Origin of Toxicity to Fungi in Wareham Heath Soil.-Dr. M. C. Rayner . . . .

Nutritive Value of Coco-nut.-Dr. J. M. Vandenbelt

Spectral Analysis of Solid Substances.-Dir. j. Eeckhout

A Tetrabromide of $\beta$-Phellandrene.-P. A. Berry and Prof. A. Killen Macbeth

Symbols Used to Indicate Hydrogen lon Concentration and Similar Quantities.-Dr. D. Clibbens

Unshrinkable Wool.-W. J. P. Neish and Prof. J. B. Speakman

A New Test for $2 \times 2$ Tables.-G. A. Barnard

Crystal Structure of Barium Titanate.-W. F. Forrester and R. M. Hinde

Particle Shape.-A. H. D. Markwick : : 177

Research Items

Swedish Oceanography during the War. By Prof. Hans

Pettersson

Ceratium and Marine Hydrography. By Prof. F. E.

Fritsch, F.R.S.

Carnegie Trust for the Universities of Scotland

Universities and the Needs of the Community

Tunas of the Pacific

A Meteoric Theory of the Origin of the Earth and

Planets

Editorial and Publishing Offices

MACMILLAN \& CO., LTD.,

ST. MARTIN'S STREET, LONDON, W.C.2.

Telephone Number: Whitehall 8831

Telegrams: Phusis Lesquare London

All rights reserved. Registered as a Newspaper at the General Post Office
ATOMIC ENERGY: AN INTERNATIONAL RESPONSIBILITY

$\mathrm{T}$

HE announcement by President Truman on August 6 that the United States Air Forces have used an 'atomic bomb' against the Japanese army base at Hiroshima was accompanied by the issue by the Prime Minister of a statement prepared by Mr. Winston Churchill some time ago on the history of the plans made in connexion with this project. The early stages of the research work involved were carried out mainly in the universities of Britain, particularly at Oxford, Cambridge, the Imperial College of Science and Technology, Liverpool and Birmingham. The Ministry of Aircraft Production was responsible for the work, being advised by a committee of scientific men. In 1941 the project was brought before the Chiefs of Staff Cornmittee, which gave it the maximum priority.

At this time a special division of the Department of Scientific and Industrial Research was set up to direct the work, which was given the title of Directorate of Tube Alloys; and a consultative council and a technical committee were appointed. Both university and industrial laboratories were pressed into service; throughout, leading men in Britain associated with the physics and chemistry of atomic structure were brought in. In the autumn of 1941, President Roosevelt suggested closer relations with American men of science working on the same subject, as a result of which there was a fusion of efforts and several workers went from Britain to the United States to continue their researches. A year later such progress had been made that it became necessary to decide where the enormous plants which would apparently be necessary for large-scale production should be erected; since Great Britain was already fully occupied and on account of the relative security from interference afforded by the United States, that country was chosen. Most of the prodigious cost now fell on the United States. Canada also came in, providing part of the raw material and facilities for one section of the work.

Such is the bare outline of the genesis of the atomic bomb, the secret of which was well kept. But the matter cannot be allowed to rest there. On the face of it, some of the ablest scientific brains of the United Nations have been devoted for a period of years to the production of an engine of destruction; this is not, however, the whole story. For many years past it has been known that the break-up of the nucleus of an atom would lead to the release of great amounts of energy; and several writers with scientific knowledge and interests have based fascinating and almost prophetic stories upon the possibility of its achievement. During all this time scientific research has been going steadily on, step by step, delving into the interior of the atom. In time, there can be no doubt that the release of atomic energy would have been achieved; but the outbreak of war, with its threat to the world, made atomic energy a prize which would speedily sway the battle, and men and resources were provided regardless of cost. As in many other cases which could be quoted, war 
sharpened the interest in research of those who control the public purse, and as a result every facility was provided for promoting an investigation which in peace-time would probably have received scanty support. It is known that the Germans as well as ourselves were seeking the solution; but, fortunately for the world, they were not able to achieve practical results.

Nevertheless, the very successfulness of the investigation induces a feeling akin to dismay that science should contribute such an engine of destruction to the world. This feeling must be put aside, though the possibilities must never be forgotten. We must remember that this new source of energy now being tapped, "long mercifully withheld from man", as Mr. Churchill wrote, can and must in the years of peace be harnessed to the needs of industry, to supplement the forms of power now in use. Research into the regulated release of atomic energy, if this has not already been achieved, will be carried on from a new basis and with redoubled energy. No doubt much painstaking work will be necessary before the new source of energy can be utilized in economic competition with fuel and wind-and waterpower, but the present position clearly holds possibilities of the utmost significance.

There is another facet of the world situation which this scientific and technical development has brought to the forefront, namely, the immense responsibility now placed in the hands of those with exact knowledge of the steps necessary to release atomic energy. It has been stated that adequate measures have been taken to secure patents on all vital processes, and all rights in such patents have been assigned to the Governments concerned. At present, this must mean that the United Nations, and especially Great Britain, the United States and Canada, hold in their hands a weapon with which they can dominate the world-. a responsibility the discharge of which will require the highest degree of statesmanship. They also hold a potential source of power capable of contributing immensely to the welfare and material progress of mankind - a further and even greater responsibility. How will they use it ? Governments are notoriously impersonal, and they come and go. It therefore devolves upon the individual, be he man of science or layman, to understand the potentialities of atomic energy, even if he comprehends little of the method of its release ; and to ensure that his elected represent. atives, from whom his Government is chosen, are also aware of their responsibilities in the matter. It is not a matter of exact knowledge so much as an appreciation of right and wrong in dealing with our neighbours, who are now every nation of the world; indeed, the alternatives would seem to be an international brotherhood of nations or chaos. There can be no question of halting investigations until mankind is fitter to receive them; if material research has outstripped the progress of knowledge of man, then the tempo of investigation of man as a social being must be increased until both can progress, side by side, carrying man onwards to the higher ideals of life for which the best of each generation are always striving.

\section{MAN-POWER AND TRAINING IN THE SCIENTIFIC INSTRUMENT INDUSTRY}

$\mathrm{T}$ an article in Nature towards the end of 1943*, attention was directed to the dependence on a live and efficient scientific instrument industry in Britain of the hopes that the technical and research resources and facilities of industry would be raised to a level which would allow of full application being made of scientific knowledge and of advancement in that knowledge. Further, it was pointed out that in no branch of industry is the need of technical knowledge and facilities greater than in the scientific instrument industry. At the time these observations were made, the manufacturers of scientific instruments and equipment were completely occupied in fulfilling the demands of the Government in respect of war requirements and, indeed, this state of affairs still persists. It is, however, reasonable to suppose that the post-war period now lies in the near, rather than in the distant, future, and it is opportune to review the position of the manufacturers of scientific instruments and of laboratory equipment in relation to their ability to meet their vital commitments to the nation during the period of the re-creation of national prosperity.

Two factors which are vital to the efficient manufacture of scientific instruments and equipment are craftsmanship and technical knowledge in its widest sense and, while neither was in a very healthy condition before the War, both have certainly been adversely affected by the War. The desperate demands on man-power of the Fighting Services during the past six years have inevitably resulted in the scientific instrument industry, in common with all other industries, being engaged in a losing battle with the Ministry of Labour and National Service for the retention of its craftsmen and technicians. Moreover, for six years the industry has been engaged in the mass-production of instruments for Service use, and it will be appreciated that, excellent as the British war-time instruments have been, there is a vast difference between the delicacy of instruments designed for accurate measurement under reasonable conditions and that of instruments required to be as accurate as possible under the very robust conditions which must exist in the tank, aeroplane and other engines of war. In consequence, the craftsmen, generally those of mature age and experience, who have remained in the industry, have not been required to exercise their craft to the full, and will, to some extent, have to regain their skill. As regards technicians, the demands of the research and development departments of the Services have been such that it has been impossible for the industry to avoid losing much of its technical personnel, and have prevented any recruitment being made by the industry to make good its technical deficiencies. Further, the large extent to which development has taken place within Service departments has reacted unfavourably on

\footnotetext{
* Nature, 152, 704 (1943)
} 